\title{
Non secretory multiple myeloma - a case report
}

\author{
Kartika W. Taroeno-Hariadi ${ }^{1}$, Ibnu Purwanto ${ }^{1}$, Johan Kurnianda ${ }^{1}$, Sagiri Mangunsudirjo ${ }^{2}$, A. Harijadi ${ }^{2}$, Puntodewo ${ }^{3}$
}

\begin{abstract}
Abstrak
Dilaporkan seorang penderita dengan multiple myeloma non sekretori, suatu varian mieloma multipel yang jarang ditemukan. Diagnosis ditegakkan berdasarkan adanya lesi litik dan keluhan nyeri tulang, anemia, hipekalsemia ringan, tidak ada gagal ginjal, protein elektroforesis dan imunoelektroforesis negatif, dan adanya kelompokan sel plasma dan sel plasma atipik pada biopsi sumsum tulang. Pemeriksaan imunofenotipik menunjukkan hasil antigen Pan-B sel negatif dan CD79a positip. Pasien mendapatkan kemoterapi kombinasi dan evaluasi pada 1 tahun kondisi tetap baik. (Med J Indones 2007; 16:257-60)
\end{abstract}

\begin{abstract}
A rare variant of multiple mieloma, non-secretory multiple myeloma (NSM), is reported. Diagnosis of NSM is made by presentations of lytic bone lesions with bone pain, anemia, slight hypercalcemia, good renal function, negative results of protein and immunoelectrophoresis detecting monoclonal gammopathy, and positive clonal proliferation of plasma cells and atypical plasma cells in bone marrow biopsy. Immunophenotypic study resulted negative pan-B cell antigens and positive CD 79a. Patient condition was improved after institution of combination chemotherapy and 1 year afterward. (Med J Indones 2007; 16:257-60)
\end{abstract}

Keywords: multiple myeloma, non-secretory multiple myeloma, diagnosis, management

Non-secretory multiple myeloma (NSM) is a condition of myeloma which is characterized by the absence of detectable monoclonal proteins in the serum and urin. ${ }^{1}$ NSM accounts $1-5 \%$ of all myeloma patients. ${ }^{1} \mathrm{NSM}$ have plasma cells that synthesize but do not secrete immunoglobulin (Ig). ${ }^{1}$ Monoclonal cytoplasmic Ig is typically present in the neoplastic plasma cells when evaluated with immunofluorescence or immunoperoxide studies, indicating a failure to secrete Ig. Due to the lack of serum or urine monoclonal Ig, the diagnosis can be missed. This is reported due to rarity and difficulties in patient's diagnosing and monitoring.

\section{CASE REPORT}

A women 42 year-old suffered from bone pain that affected sternal, clavicular, cervical and hip bone. The

\footnotetext{
${ }^{1}$ Division of Hematology and Medical Oncology, Department of Internal Medicine, Dr Sardjito Hospital, Faculty of Medicine, Gadjah Mada University Yogyakarta, Indonesia

2 Department of Pathology, Dr Sardjito Hospital / Faculty of Medicine, Gadjah Mada University, Yogyakarta, Indonesia.

${ }^{3}$ Department of Surgery, Dr Sardjito Hospital/ Faculty of Medicine, Gadjah Mada University, Yogyakarta, Indonesia
}

pain was so severe and caused disability of movement. She was not able to raised or sit without any help. This condition was felt for almost 1 year.

Patient condition was weak, performance scale of WHO 3, good consciousness. She looked pale. Visual analog scale was 9 . Blood pressure 110/80 $\mathrm{mmHg}$, heart rate was $80 \mathrm{x} /$ minute, respiration rate: $20 \mathrm{x} /$ menit. No lymphnode enlargement, no organomegaly, and no palpable mass detected from breast and gynecological organ. Laboratory results: $\mathrm{Hg}: 5.2 \mathrm{~g} / \mathrm{dl}$ WBC:9.6x $10^{3} / \mathrm{uL}$ HCT:18.9\% MCV: 93.6 fl MCH:28.0 pg MCHC: $30.2 \mathrm{~g} / \mathrm{dL}$ PLT $474 \times 10^{3} / \mathrm{uL}$ ANC:5,9x $103 / \mathrm{uL}$ AST: 19 U/L ALT:12 U/L BUN:7.0 mg/dL Creatinin: $0.9 \mathrm{mg} / \mathrm{dL}$ Uric acid:7.0 mg/dL Calcium: $3.05 \mathrm{mmol} / \mathrm{L}$ Protein: $8.6 \mathrm{~g} / \mathrm{dL}$, albumin: $3.1 \mathrm{~g} / \mathrm{dL}$ globulin: $5.5 \mathrm{~g} / \mathrm{dL}$

Peripheral Blood morphology was normal. Breast USG and mammography: normal.

Gynecological examination, pap's smear, radiological diagnosis were normal.

Chest X-ray showed reticular pattern distributed in both side of lung and lytic pattern on bilateral clavicle, bilateral scapula, humerus. and costae. Bone 
survey resulted widely-distributed lytic lesions on skull, bilateral clavicles, scapula, costae, humeri, cervical bones, vertebra lumbales, iliac, ischial, femoral bones.

Protein electrophoresis results: Albumin: $4.6 \mathrm{~g} / \mathrm{dL}$ alpha 1:0.1 g/dL alpha 2:0.7 g/dL Beta:2.4 g/dL gamma: $0.8 \mathrm{~g} / \mathrm{dL}$ A/G ratio: 1.16

Bence-Jones urine was negative. Serum protein immunofixation showed no monoclonal gammopathy pattern.

Bone marrow aspiration was unsuccessfully performed. Bone biopsy showed cluster of plasma cells, >30\%, and atypical plasma cells. Immunohistochemistry was performed and resulted in negative CD10, negative CD20, and positive expression of CD 79a in more than $30 \%$ of tumor cell /atypical plasma cell.
Diagnosis is established as NSM. Patient received blood transfusion. Hemoglobine increased to $11.6 \mathrm{~g} / \mathrm{dL}$. Patient received combination chemotherapy with Vincristine $0.4 \mathrm{mg} / \mathrm{m}^{2}$ iv continuous infusion (day 1-4), Doxorubicin $9 \mathrm{mg} / \mathrm{m}^{2}$ iv continuous infusion (day 1-4), Dexamethasone $40 \mathrm{mg} / \mathrm{m}^{2}$ (day $1-4 ; 9-12 ; 17-20$ ) regimens for 6 cycles. Zolendronic acid injection is given for only six cycles followed by clodronate injection due to financial problem.

Symptoms were improved after chemotherapy. Patient was able to walk and do her daily activity without any help. Bone lytics were still present at the end of treatment. Patient condition is stable during one-year follow up.
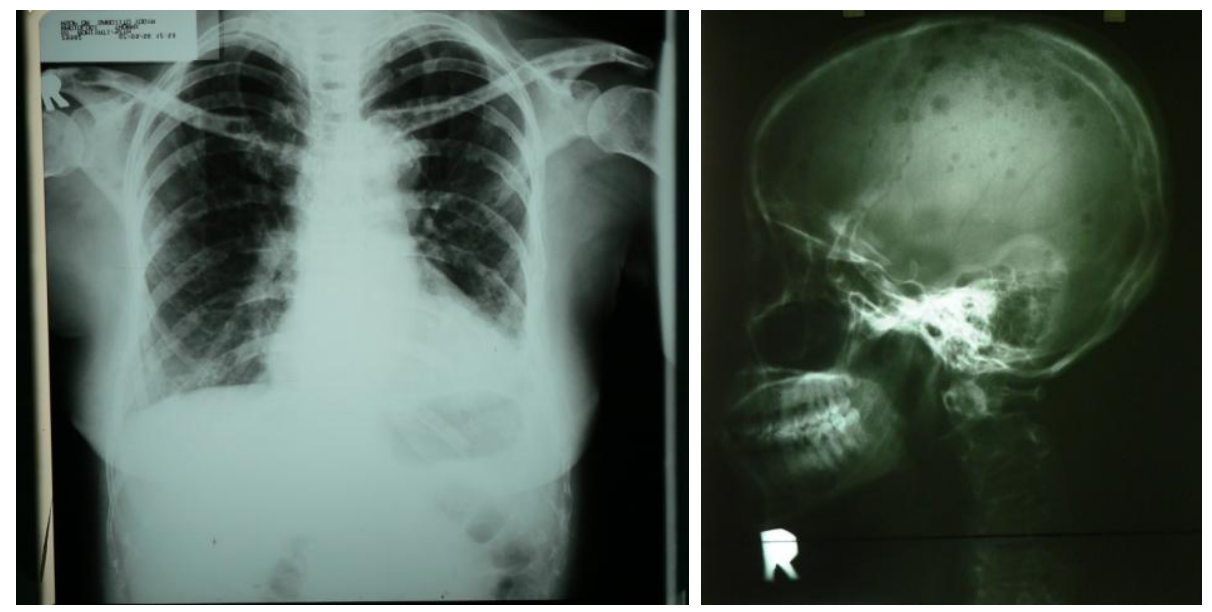

Figure 1. Lytic lesion on clavicles, scapula, humerus, and skull

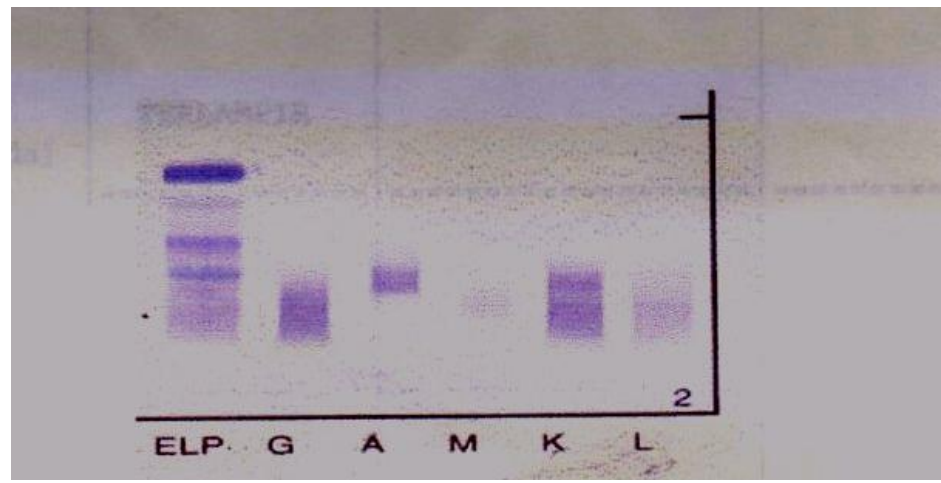

Figure 2. Normal serum protein electrophoresis using immunofixation technique 


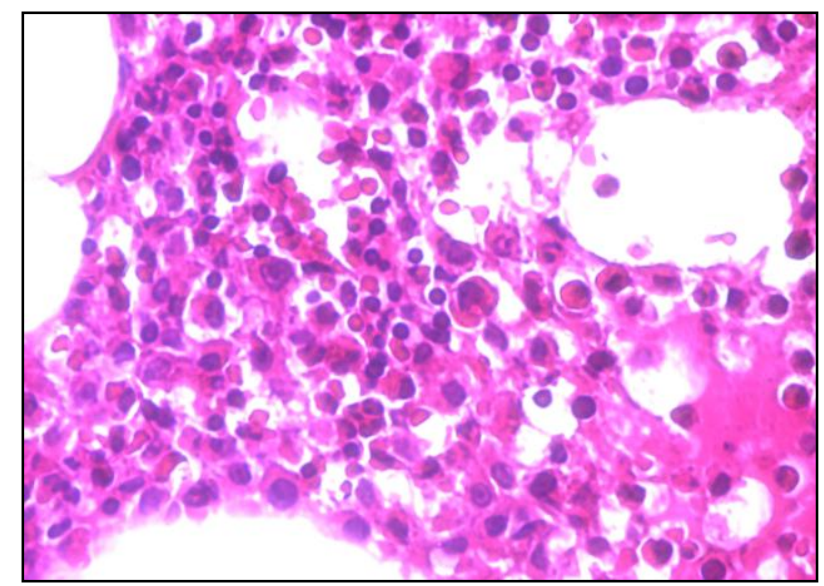

Figure 3. Bone biopsy stained with HE shows plasma cell myelomas which have eccentric nuclei, pleomorphic with frequent multinucleate cells. Some of them have clock-face chromatin

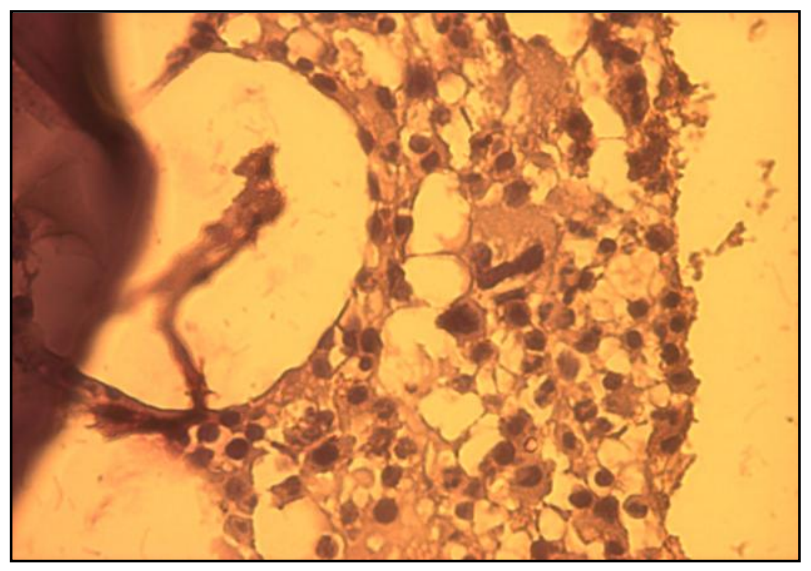

Figure 4. CD79a expression on myeloma cells

\section{DISCUSSION}

The primary manifestation of NSM is bone lytic, anemia, slight hypercalcemia which is indistinguishable with bone metastasis. Bone destruction, the same as seen in multiple myeloma, is responsible for the most distressing clinical feature of NSM. Bone lytics usually takes place in the skull, sternum, ribs, humerus, pelvis. ${ }^{2}$

The clinical manifestation of NSM are identical to plasma cell myeloma, except for lower incidence of renal insufficiency and a better prognosis. ${ }^{1,3}$ The diagnosis of non-secretory multiple myeloma is assessed by lytic bone lesion, anemia, hypercalemia, and a normal serum and urine protein electrophoresis and immunoelectrophoresis. Sometimes it become even more difficult to make diagnosis of NSM due to lower percentage of plasma cell in marrow ${ }^{3}$ and the fact that bone marrow aspirate obtained from routinary site (sternal and hip) often only showed a picture consistent with generalized medullary reaction against chronic infection or metastasis. ${ }^{4}$ By specific study from osteolytic area myelomatous tissue can be found. ${ }^{4}$

The reason for absence of detectable paraprotein in NSM has become a subject for debate. Sometimes the intracellular immunoglobulin can be detected in plasma cells implying defective in Ig secretion or abnormal Ig structure which is not capable of being transmitted by secretory pathway. ${ }^{4,5}$ In some cases plasma cells produce small amount of Ig can not be detected by conventional technique. ${ }^{6}$

Immunophenotype of non secretory plasma cell myeloma usually shows cytoplasmic Ig, lack of surface marker of Ig, lack of CD 19,CD 20, CD10, but expresses CD 38 (marker for activated T cell, early B and T cell, and plasma cell) and CD79a (Ig-associated protein marker). ${ }^{1}$ Cytoplasmic Ig and CD 38 marker are not available in our centre. Using cytoplasmic Ig monoclonal antibodies, clonality of Ig that is produced by plasma cells but is not secreted can be detected.

Serum free light-chain was not measured in our patient. With a sensitive immunoassay to detect free light-chains for about 1-5 \% cases of previously diagnosed NSM can be detected serum free lightchain secretion. Diagnosis of NSM should be modified to exclude clonality of light-chain that can be detected by recently developed nephelometric light-chain assay. ${ }^{6}$ Using sensitive techniques diagnosing and monitoring of NSM is more possible. ${ }^{6,7}$

Treatments of NSM are the same as secretors. Melphalan-Prednison is remain a standard regiment for symptomatic patients over 70-year old and younger patients who are not candidate for transplantation. More aggressive chemotherapies do not show superiority over Melphalan. VAD, the less myelotoxicity regiment, can be used as initial treatment for myeloma patients who are candidates for transplantation. ${ }^{2}$ Biphosphonates are recommended for patients with bone lytic. Zolendronic acid $4 \mathrm{mg}$ or Pamidronate $90 \mathrm{mg}$ is given every 3-4 weeks. Once initiated the uses of biphosphonate should be continued until there is a substantial decline of patient's performance status. Clinical judgment must be pointed at palliative benefit of intravenous biphosphonate over the inconvenience of using biphosphonate injection. Intermittent evaluation for albuminuria 
and azotemia should be performed in patients with chronic biphosphonates treatment. $^{8}$

In this case we faced difficulties in assessing treatment's response due to lacks of paraparotein in the serum and urine. Response assessment is only based on radiological assessment and plasma cell count in bone marrow. Survival is significantly longer in NSM than secretors, 46 months vs 21 months. ${ }^{3}$

\section{REFERENCES}

1. Grogan TM, Van Camp B, Kyle RA, Muller-Hermelink HK, Harris NL. Plasma Cell Neoplasma. Pathology \& Genetics Tumours of Haematopoietic and Lymphoid Tissues. ES Jaffe, NL Harris, H Stein, JW Vardiman eds. WHO Classification of Tumor IARC Press, Lyon. 2001: 142-56

2. Dave SS, Dunbar CE. Multiple myeloma. Handbook of Clinical Hematology. Rodgers DP, Young NS eds. Lippincott Williams \& Wilkins Philadelphia, 2005
3. Smith DB, Harris M, Gowland E, Chang J, Scarffe JH. Non-secretory multiple myeloma: a report of 13 cases with a review of the literature. Hematol Oncol. 1986 OctDec;4(4):307-13

4. Bartolini C, Flamini G, Logroscino C. IgD(Kappa) Nonsecretory Multiple Myeloma-a report of a case. Blood. 1980: 56(5):898-901

5. Shaw GR. Non Secretory Plasma Myeloma - Becoming Even More Rare Using Serum Free Light-Chain Assay. Arch Pathol Lab Med. 2006: 130:1212-5

6. Sheehan T, Sinclair D, Tansey P, O'Donnell JR. Demonstration of Serum Monoclonal Immunoglobulin in a case of Non-Secretory Myeloma by Immunoisoelectric Focusing. J CLin Pathol. 1985:38:806-9

7. Drayson M, Tang LX, Dre R, Mead GP, Carr-Smith H, Bradwell AR. Serum free light-chain Measurement for Identifying and Monitoring Patients with Non-Secretory Multiple Myeloma. Blood. 2001: 97: 2900-2

8. Berenson JR, Hillner BE, Kyle RA. American Society of Clinical Oncology Clinical Practice Guideline: The role of Biphosphonates in Multiple Myeloma. J Clin Oncol. 20:3719-36 
